\title{
Guidelines for university library services to undergraduate students Approved at ALA Annual Conference, June 2005
}

\author{
by the ACRL Undergraduate Librarians Discussion Group
}

$\mathrm{T}$ hese guidelines are intended to apply to library services to undergraduate students at university libraries and to be used in conjunction with the ACRL "Standards for libraries in higher education" (2004, www.ala.org/ala/acrl/acrlstandards /standardslibraries.htm). At some institutions a separate undergraduate library may exist; at others, staff and programs devoted to undergraduates may be present in the context of the general library. References to undergraduate library services in these guidelines apply to both of these contexts. The guidelines are designed as a tool to help those providing services to undergraduate students in a large university setting establish individual goals for developing, maintaining, and expanding those services within the context of their library's and university's goals.

These guidelines provide both a quantitative and a qualitative approach to assessing the effectiveness of undergraduate programs and services. They advocate the use of input, output, and outcome measures in the context of the general library's mission statement and goals, and they encourage comparison of these measures with those of peer institutions.

The results of the assessments outlined in the guidelines can be used within the library to raise awareness of the strengths and weaknesses of current library services to undergraduates. The results can be used during strategic planning by providing con- crete baselines and goals. In library public relations with colleagues and throughout the campus, the assessment results can be incorporated into promotional materials for undergraduate services.

\section{Campus environment}

Library systems at universities generally consist of a main university library plus several branch or special libraries. The large campus environment often defines the quality of the library in terms of the strengths and size of the research collection. Concentration of the main and branch libraries is frequently on the needs of specific fields or departments of study at a research level.

The needs of academic library users fall on a spectrum, with use of introductory research materials and instruction in the research process at one end and primary source materials and highly specialized research services at the opposite end. Because the strong emphasis on research can create an intimidating environment for many undergraduate students, undergraduate library services focus on introductory materials and instruction. Although undergraduates use materials from all parts of the research collection, the library should provide services, resources, and instruction specifically designed to educate and inform them and to enable them to become more self-sufficient researchers. The separate undergraduate library, where it exists, provides a designated place in which undergraduates 


\section{About the guidelines}

In 2002, ACRL's University Libraries Section (ULS) ad hoc Standards and Guidelines Committee asked the Undergraduate Librarians Discussion Group to consider whether the newly created "Standards for libraries in higher education" (www.ala.org/ala/acrl/acrlstandards /standardslibraries.htm) would adequately update and replace the 1997 "Guidelines for university undergraduate libraries." After substantial and mutually enlightening discussion, the committee and discussion group agreed that guidelines for library services to undergraduate students were still needed.They further agreed that new guidelines should broaden the scope of the 1997 document to include services to undergraduate students in all research library settings, not only those with separate undergraduate libraries. They also agreed that the new guidelines would be designed for use in conjunction with the "Standards for libraries in higher education."

The Undergraduate Librarians Discussion Group took up the work of creating these guidelines at ALA's 2003 Midwinter Meeting, and work continued until the 2005 Midwinter Meeting. The resulting draft was submitted to and endorsed by the ULS Executive Committee at ALA's Midwinter Meeting in Boston in January 2005. Chair of the ULS Standards and Guidelines Committee was Lori Goetsch (Kansas State University). Undergraduate Librarians Discussion Group chairs during this time were Carolyn Walters (Indiana University) and Leah McGinnis (University of North Carolina). Members of the discussion group who worked directly on drafts of the document were Jeff Kosokoff (Harvard University), Jill McKinstry (University of Washington), Jennifer Nardine (University of Michigan), and Linda TerHaar (University of Michigan).

The final version of the guidelines were subsequently approved by the ACRL Board of Directors at its June 2005 meeting. The approved guidelines supersede the 1997 "Guidelines for university undergraduate libraries" as well as "The mission of an undergraduate library: Model statement" (1987).

are the primary focus, for whom the space is specifically designed, and in which they are not displaced by faculty or graduate students. In order to achieve the desired level of service, it is important to have specific library staff members who understand undergraduate needs and who are devoted to undergraduate services.

Effective undergraduate services require adequate resources to accomplish their mission. Implicit in the creation of undergraduate library services is a commitment to funding their development, ongoing services, and growth while maintaining library services for the entire academic community. Standards and quality of library service to undergraduates should be comparable to library services offered to other patrons at the university.

\section{Primary clientele}

Undergraduate students enter the university with varying levels of experience and information skills and share many of the following characteristics:

- They are beginning to acquire the research skills needed to exploit the university library's potential.

- They need a user-friendly environment, where assistance is offered and questions are encouraged.

- They need to be introduced through library instruction, either one-on-one or through coursework, to the academic nature of the services and resources available in university libraries.

- They are most often enrolled in courses where assignments have short deadlines requiring timely library services. These courses often have large enrollments.

- They are often enrolled in mandatory introductory courses that fulfill distribution requirements, but are not necessarily in their field of interest. 
- They are frequently the largest component of the campus population, yet often have the least political clout.

\section{Otber clientele}

Library services designed for undergraduates may also serve the instruction and information needs of university staff and faculty, as well as members of the civic community. As such, they are a gateway to the university libraries for the entire community.

\section{Points of comparison}

Undergraduate librarians are encouraged to choose their own peer libraries for the purpose of comparisons, depending on the needs of the library. The university or university library may have already established peer groups and relationships for various performance comparison and benchmarking purposes, or the library may define other peer groups for specific comparisons for services to undergraduate students. Once a peer group has been determined, points can be chosen to compare the strength of undergraduate services with those peers. The library should determine points of comparison.

Possible points of comparison: Input measures

1. Budget and staffing devoted explicitly to undergraduate services.

2. Physical facilities that support undergraduate services, research and study needs, and provide an effective learning environment.

3. Ratio of number of students attending library instructional sessions to total number of students in specified target groups, e.g., first-year students or students in introductory-level courses.

4. Collection resources supporting the undergraduate curriculum, research needs, and undergraduate information-seeking modes.

5. Measure of resources spent on outreach, e.g., instruction sessions, services outside of the library walls, collaborations with units outside the library.

Possible points of comparison: Output measures

1. Ratio of reference transactions to student/patron FTE, including transactions that occur in any venue, whether face-toface or virtual.

2. Ratio of borrowing, excluding reserve, by undergraduates to undergraduate student FTE.

3. Ratio of reserves borrowing and ereserves use for undergraduate courses to total of students in target classes.

4 . Number and variety of outreach programs per semester.

5. Ratio of successful searches for library resources to total searches.

6. Average number of people in the library at a given time.

7. In-library materials use as separate from circulation counts.

8. Ratio of patron FTE to service point use.

9. Number of links from Web sites outside the library (e.g., from class Web sites, online course directories) to undergraduate, class-specific Web sites created by undergraduate librarians.

10. Ratio of orientation attendees to incoming student FTE.

11. Number and kinds of partnerships with other entities on campus.

\section{Planning, assessment, and outcomes assessment \\ Planning}

The general library mission statement and goals serve as a framework for its activities, including services for undergraduates. A separate undergraduate library or division and the staff devoted to undergraduate services should have their own goals and mission statement compatible and consistent with those developed by the general library. In order to build programs and services in the context of the library, those responsible for services to undergraduate 
students should be involved in the library's overall planning process. This planning process provides an overall direction that helps to guide day-to-day activities and decisions regarding services to undergraduate students.

\section{Assessment}

The changing nature of the primary clientele and the curriculum necessitates continuous evaluation and assessment of undergraduate services. Periodic, formal performance review findings will augment ongoing undergraduate service evaluation processes. Review criteria and frequency will vary depending on the parent institution. The outcome of reviews will lead to goals and expectations of future undergraduate services. Assessment should include a sampling of undergraduates who use library services and those who do not. Surveys and other information gathering from undergraduates can be coordinated with and integrated into the library's overall assessment program.

\section{Possible assessment tools}

1. General library knowledge surveys or pre-tests offered to incoming first-year students or to those attending an instruction session, re-offered at the end of the session or at various points in the students careers, to assess whether the library's curricular instruction is producing more information-literate students.

2. Evaluation checklists for instruction in all forms, whether face-to-face or virtual, to gather feedback from students, other librarians, and teaching faculty.

3. Student journal entries, or information literacy diaries, used to track their library use.

4. Focus groups of undergraduate students who comment on their experiences using library services, resources, or facilities, including non-study and research use, and on how well they think the library understands and meets their needs and preferred way of working.

\section{Outcomes assessment}

As established in the ACRL "Standards for libraries in higher education," outcomes assessment can be an active mechanism for improving current library practices. It focuses on the achievement of outcomes that have been identified as desirable in the library's goals and objectives both in the big picture and, specifically, for undergraduate services. Outcomes assessment identifies performance measures, such as proficiencies, that indicate how well the library is doing what it has stated it wishes to do. Libraries' greater dependence on technology, their increasing use of online services, their growing responsibility to provide information literacy skills, their increasing reliance on consortial services, the possibilities of dwindling financial resources for collection development, and new developments in the ways in which scholarly information is published and distributed have measurable effects on undergraduate libraries' ability to provide cost-effective support for student achievement.

Assessment instruments may include surveys, tests, interviews, and other valid measuring devices. Colleagues at peer institutions may render invaluable assistance by suggesting assessment questions and sample sizes, by sharing lessons learned, and by suggesting alternative methods for measuring outcomes.

Possible outcomes assessment tools and areas

1. Focus groups of students and alumni who are asked to comment on their experiences using information resources over a period of time.

2. Staff and administration's understanding of the library's service mission to undergraduates.

3. Degree to which the university's mission is incorporated into the goals and objectives of library services to undergraduates.

4. A systematic and continuous program for evaluating performance. 
5. A systematic and continuous program for informing the community of accomplishments.

6. A systematic and continuous program for identifying and implementing needed improvements or new approaches.

7. Assessment of undergraduate services included as an integral component of the library's assessment program.

8. A standard set of assessment tools across undergraduate library service areas that expedite direct comparison with performance at peer institutions.

\section{Services}

Effective, high-quality undergraduate library services successfully support the undergraduate programs of the institution. To facilitate academic success, library services to undergraduates must provide access to a broad range of information resources. Reference and referral services, orientation activities, and instruction sessions that teach students the critical thinking skills necessary for using library resources are basic services provided by undergraduate library personnel. Varied and innovative undergraduate teaching programs include teaching by personal contact and through the preparation and use of instructional materials in various formats, formal group instruction, and informal, unstructured contacts with students. Undergraduate library services provide a laboratory for students to acquire information literacy skills: identification of needed information, effective and ethical use of intellectual and physical resources, and knowledge of when to ask for help as well as the confidence to do so. Undergraduate library services provide a gateway to all future library inquiry, not only preparing students for graduate work and research but also teaching them to use information sources as citizens, as consumers, as professionals, and for recreational purposes.

\section{Reference services}

Reference services for undergraduates often involve not only answering specific questions, but also personalized instruction in the methods of identifying and locating research materials. Databases, bibliographies, and other aids designed to introduce undergraduates to the material the library provides and to guide them in finding the research material further enrich the pool of available resources. Reference service provided by undergraduate librarians introduces the wide variety of resources in the library system and beyond, connecting undergraduates with branch or specialized libraries, and other campus supportive services, including academic, financial, writing, and counseling services.

Orientation activities may take many forms, but all acquaint undergraduates with the facilities, resources, and services of the library system for the first time. Orientation may also include public relations activities that introduce students to information resources available within the university community or on any information network.

\section{Questions regarding reference services}

1. Do the services offered meet the information needs of the undergraduate students, and the faculty and staff who work with them?

2. Are user studies, statistics, and other measures of quantity and quality collected and used effectively?

3. What is the ratio of public services staff to the number of primary clientele? Is this an acceptable ratio in the context of the library's mission?

4. Are additional services or added availability of existing services needed?

5. Are new services, which are needed by users, anticipated and implemented?

6. Are there any services that have become obsolete and could be eliminated?

\section{Instruction}

Library instruction programs should improve the students' ability to use library collections and services effectively, and should include instruction in the use of 
the full range of information and knowledge resources. Instruction may be offered as part of coursework in an academic subject or interdisciplinary program, in a separate course on research skills and information literacy, in workshops, in network-delivered instruction, in term-paper clinics, and through point-of-use aids in the library. Standards and guidelines for information literacy and instruction are useful tools in developing and assessing library instruction. Standards and guidelines on the topic of information literacy are available on the ACRL Web site www.ala.org/ala/acrl/acrlstandards /standardsguidelinestopic.htm.

\section{Questions regarding instruction}

1. Are library instruction programs available and funded adequately for the support of coursework?

2. Are instruction programs integrated with undergraduate coursework?

3. How easily can undergraduates access instruction when they need it?

4. Are library instruction programs informed by current research, principles, and knowledge?

\section{Resources and collections}

The library should provide varied, authoritative, and up-to-date resources that support its mission and the needs of undergraduate users.

Undergraduate collections provide ready access to information resources that meet the needs of their primary clientele, with focus on the institution's curriculum. The value of undergraduate collections is measured by their usability as well as quality and size. Electronic resources form a significant part of the information network needed and preferred by undergraduates.

There is no absolute standard for the size of a collection supporting undergraduate needs. The essential criterion is that the resources available to undergraduate researchers adequately support their needs. The library's collection policy should ad- equately describe this goal. Collection and access policies should be written, up-todate, and readily available.

Undergraduate collection policies consider the following

1. Because many undergraduate courses require large numbers of students to use the same library materials, direct curriculum support may be provided through reserve collections of physical or electronic items. Electronic items may be integrated into course management systems.

2. Undergraduate collections provide effective access to information resources through reference sources in a variety of formats. Reference collections for undergraduates provide standard and interdisciplinary indexes and sources.

3. Undergraduate subject coverage encompasses a broad range of disciplines to offer the information needed for papers, essays, presentations, and projects required in the wide variety of courses taken by undergraduates. More specialized and advanced needs will be met by specific referral to other library sources on campus.

4. The library experience of undergraduates should encourage them to seek information of personal interest. Collection policies should include access to information on current events, cultural interests, careers, and recreational reading, among others, to encourage exploration of information resources as a part of everyday life.

5. Collection policies for separate undergraduate libraries should include withdrawal and relocation practices because of the special nature of undergraduate collections. Collections should be dynamic and responsive to the needs of a changing curriculum and clientele.

\section{Access}

As information technology (IT) evolves, undergraduate library services must continually upgrade hardware, software, and other IT resources to keep pace with the 
needs and expectations of their primary clientele. Undergraduate students are most familiar with up-to-date technology and are among the earliest adopters of the latest tools and techniques. Thus, rapid changes in IT demand especially aggressive and proactive planning for undergraduate services. Resources dedicated to IT should not only be allocated towards maintenance of current facilities, but also towards the development and revision of services and technologies that students will need in the future.

\section{Questions}

1. Does the collection profile adequately support the undergraduate curriculum?

2. Does the size and depth of the collection adequately support the size and needs of the undergraduate population?

3. Are materials appropriately available and accessible for reserve users?

4. Are collections housed and arranged efficiently and effectively for use by the primary clientele?

5. Are collections available and accessible to all users? Do circulation policies and practices permit effective access for users?

6. Do appropriate withdrawal policies and practices exist to adequately address the need for collection maintenance?

7. Does the library have adequate, up-todate technology options in place?

8. Are access policies posted to ensure that all users are aware of services and restrictions?

9. Are interlibrary loan and other document delivery services provided for undergraduates to give them access to materials not owned by the institution?

10. Do undergraduates have adequate access to information technology for accessing and working with information?

\section{Staff}

Library staff serving undergraduate students have the knowledge and abilities to ensure effective management and use of the library's services and resources. In general, undergraduate services require librarians as well as support and part-time staff, depending on the size of the undergraduate population at the institution. The ability to interact on a one-toone basis with a diverse clientele in a friendly and instructive manner is essential.

Personnel serving undergraduate students require diverse backgrounds in order to meet the teaching and learning needs of users. Abilities needed include: teaching and knowledge of instructional methods and learning styles, excellent communication skills, and understanding and expertise in informationseeking skills. Flexibility and willingness to take risks and develop innovative programs are essential. Undergraduate librarians should participate in appropriate professional organizations and take the lead in assuring awareness of special issues affecting undergraduate library services.

\section{Questions}

1. Are staff members adequately trained? Is staff development encouraged and supported?

2. What is the ratio of staff to the number of primary clientele? Is this an acceptable ratio within the particular campus context?

\section{Facilities}

Undergraduate library services require appropriate facilities to accomplish their missions. Separate undergraduate libraries should have facilities that foster the collaborative nature of study, research, and learning, and that promote effective and interactive access and use of information resources. Safe, comfortable, well-lit, clean space with adequate and appropriate study, research, and collaboration space will ensure effective use of the library's resources, including electronic resources. In physical planning for facilities, undergraduate libraries provide for small group and instructional use. Additionally, more than other libraries within the university, separate undergraduate libraries consider study and collaboration needs in allocation of seating and space, with attention to the learning environment of the institution. Undergraduate libraries establish hours of access, circulation 
policies, and other rules to meet the needs of their primary clientele.

Undergraduate services housed within larger libraries must still consider and provide for the needs of their primary clientele. Adequate space specifically for undergraduate study and research will encourage undergraduates to use library resources.

\section{Questions}

1. Are the facilities safe and environmentally controlled?

2. Do facilities foster collaboration, communication, and cooperative learning among students?

3. Are materials adequately safeguarded against loss, mutilation, theft, or other damage?

4. Is adequate equipment and technical support available?

5. Is appropriate seating and user space available for the varieties of ways students need to be able to work?

6. Is space appropriately allocated for use, including group and instructional use, study, research, use of information technologies?

7. Are facilities accessible to all users?

8. Does space allow for cooperative programs with other library and campus units?

\section{Administration}

Administration responsible for undergraduate services must ensure the continued relevance of the services. Administration represents undergraduates and their needs in the greater library system context, and promotes the value of undergraduate library services in that context. Undergraduate library administrators serve as liaisons between the university and library administrations and the undergraduate library unit and students. In order to understand and accurately represent the needs of the undergraduate population, the undergraduate administration needs regular, direct contact with patrons and with staff.

\section{Questions}

1. How does undergraduate services administration communicate the values and needs of undergraduate services to the greater library system and the university administration?

2. Do undergraduate services have a sufficient voice in the greater library system?

3. How does the administration gather information regarding library performance from staff and patrons?

4. How often does the administration have direct contact with the primary patron base?

\section{Budget}

Effective undergraduate services require adequate resources to accomplish their missions. Implicit in the creation of undergraduate services is an institutional commitment to funding their development, ongoing services, and growth as an integral part of maintaining library services for the entire academic community.

\section{Questions}

1. Are the resources available comparable to those for undergraduate services at comparable institutions?

2. Does the budget support appropriate levels of staffing?

3. Does the budget provide adequate support for baseline services?

4. Does the budget adequately support the collection policy to provide materials or access to materials in support of undergraduate students' library needs?

5. Is the budget flexible enough to support necessary new programs and innovations, including integration of new technologies and instruction programs?

6. Are the library and information needs of undergraduate students represented adequately in the budget process?

7. Does the undergraduate services personnel have discretion and control of its budget?

8. Do staffing and budget allocations allow for long-term planning initiatives? $\mathbf{z}$ 